\title{
Tolerance to flooding in five Brachiaria brizantha accessions ${ }^{(1)}$
}

\author{
Moacyr Bernardino Dias-Filho(2)
}

\begin{abstract}
Some physiological and morphological responses of five Brachiaria brizantha accessions (BRA000591 cultivar Marandu, BRA003441, BRA002844, BRA004308 and BRA004391) were compared for plants grown in pots under flooding and well-drained conditions for 14 days. Flooding caused a significant reduction in leaf dry mass production in all accessions, but, for root biomass, no differences between treatments could be detected in BRA003441 and BRA004391. No adventitious root production was observed in flooded BRA003441; all other accessions produced adventitious roots when flooded. Relative growth rate was reduced by flooding only in BRA000591 and BRA004308. Leaf elongation rate was reduced by flooding in all accessions, however, more severely in BRA003441. Net photosynthesis was reduced by flooding in all accessions, but with less intensity in BRA004391. For all accessions, there was a close relationship between net photosynthesis and stomatal conductance under flooding. The five accessions tested differed in tolerance to flooding. BRA004391 was the most tolerant. Accession BRA003441 was the most sensitive, followed by BRA000591 cultivar Marandu. Accessions BRA002844 and BRA004308 were classified as intermediate in flooding tolerance.
\end{abstract}

Index terms: adventitious roots, photosynthesis, forage grasses, biomass allocation, growth rate.

Tolerância ao alagamento em cinco acessos de Brachiaria brizantha

Resumo - Algumas respostas morfológicas e fisiológicas de cinco acessos de Brachiaria brizantha (BRA000591 cultivar Marandu, BRA003441, BRA002844, BRA004308 e BRA004391) foram comparadas em plantas cultivadas em vasos, sob condições de solo alagado e bem drenado, durante 14 dias. O alagamento reduziu significativamente a produção de massa seca foliar em todos os acessos, mas para a massa seca radicular, não foi possível encontrar diferenças entre tratamentos em BRA003441 e BRA004391. Somente BRA003441 não produziu raízes adventícias sob alagamento. A taxa de crescimento relativo foi reduzida pelo alagamento somente em BRA000591 e BRA004308. A taxa de elongação foliar foi reduzida pelo alagamento do solo em todos os acessos, porém, com maior severidade em BRA003441. O alagamento reduziu a fotossíntese líquida em todos os acessos, porém, menos intensamente em BRA004391. Em todos os acessos encontrou-se uma estreita relação entre as taxas de fotossíntese líquida e a condutância estomática sob alagamento. Os cinco acessos testados diferiram na sua tolerância relativa ao alagamento do solo. BRA004391 foi o mais tolerante. O acesso BRA003441 foi o menos tolerante, seguido por BRA000591 cultivar Marandu. Os acessos BRA002844 e BRA004308 foram considerados como intermediários em tolerância ao alagamento do solo.

Termos para indexação: raízes adventícias, fotossíntese, gramíneas forrageiras, alocação de biomassa, taxa de crescimento.

\section{Introduction}

In agricultural habitats, intermittent short- or long-term soil flooding can result from storms, inadequate soil drainage, or overflowing of rivers. While in some regions soil flooding is a rare event, in

\footnotetext{
(1) Accepted for publication on July 10, 2001.

(2) Embrapa-Centro de Pesquisa Agroflorestal da Amazônia Oriental, Caixa Postal 48, CEP 66017-970 Belém, PA CNPq Fellow. E-mail: moacyr@cpatu.embrapa.br
}

others it is a chronic problem, severely limiting agricultural activities. Due to the fact that in many tropical regions pasture areas are usually located in marginal areas not suited for agriculture (Dias-Filho, 1998), they can be more commonly subjected to soil flooding or waterlogging.

Flooding causes an immediate reduction in the exchange of gases between the plant and its environment (Armstrong et al., 1994; Kozlowski, 1997). Mechanisms of tolerance to flooding are based on many adaptive features and strategies that 
improve gas exchange and maintain energy production (Armstrong et al., 1994).

The extent to which tropical pasture grasses may be flood tolerant and the mechanisms involved in flooding response of these plants have received very few investigation (Medina \& Motta, 1990; Baruch, 1994a, 1994b; Kibbler \& Bahnisch, 1999; Dias-Filho \& Carvalho, 2000; Ram, 2000), and most of what is known about flood tolerance of tropical forage grasses is based on anecdotal evidence, mostly published in the gray literature.

Pastures in tropical areas typically experience flooding during the rainy season, a period of intense physiological activity. This can enhance any deleterious effect caused by flooding in plants with limited tolerance to this stress, and also prevent these plants from developing adequately (e.g., produce larger root systems) to cope with the subsequent dry season. Thus, knowing how tropical pasture species respond to flooding is important in determining their potential of use in habitats prone to this stress.

Brachiaria brizantha (Hochst. ex A. Rich.) Stapf cultivar Marandu is an important forage grass throughout the tropics and, particularly, in tropical America (Argel \& Keller-Grein, 1996). New accessions of this species are now being tested in Brazil by Embrapa (Simão Neto et al., 1995), in an effort to release new forage grass cultivars. Very little is known about how these new accessions may respond to environmental stresses commonly found in tropical habitats.

The objective of this study was to compare the flooding tolerance of five accessions of $B$. brizantha, by subjecting the plants to soil flooding during a 14-day period.

\section{Material and Methods}

Seeds of Brachiaria brizantha (Hochst. ex A. Rich.) Stapf BRA000591 cultivar Marandu, BRA003441, BRA002844, BRA004308 and BRA004391, supplied by Embrapa-Centro Nacional de Pesquisa de Gado de Corte, in Campo Grande, MS, Brazil, were germinated on sand and then planted individually in pots with $2 \mathrm{~kg}$ (dry weight) of soil (1:1; organic soil to sand). Two days after planting, pots were fertilized with a solution of $40 \mathrm{mg}$ of $\mathrm{P}$ $\left(\mathrm{K}_{2} \mathrm{HPO}_{4}\right) \mathrm{kg}^{-1}$ soil. Plants were grown outdoors for the duration of the experiment under a shade net that intercepted ca. $60 \%$ of direct solar radiation. The trial was conducted at the Embrapa-Centro de Pesquisa Agroflorestal da Amazônia Oriental, in Belém ( $\left.1^{\circ} 28^{\prime} \mathrm{S}\right)$, North Brazil. Each pot was watered daily and fertilized every other day with $10 \mathrm{~mL}$ of a water soluble fertilizer solution (15:30:15; $\left.\mathrm{N}: \mathrm{P}_{2} \mathrm{O}_{5}: \mathrm{K}_{2} \mathrm{O} ; 5 \mathrm{~g} \mathrm{~L}^{-1}\right)$. Seven days after planting, pots were fertilized with $50 \mathrm{mg} \mathrm{N}$ (urea) $\mathrm{kg}^{-1}$ soil. Flooding was imposed 13 days after planting by inundating the pots up to $3 \mathrm{~cm}$ above the soil level and control pots were free-draining and watered daily. Flooding lasted 14 days for all accessions. The periodical fertilization with NPK $\left(15: 30: 15 ; \mathrm{N}: \mathrm{P}_{2} \mathrm{O}_{5}: \mathrm{K}_{2} \mathrm{O} ; 5 \mathrm{~g} \mathrm{~L}^{-1}\right)$ was maintained on both treatments during all the experiment. All plants remained vegetative during the experimental period.

Three harvests were made; the first harvest was on the day flooding treatment was imposed (ca. 21 days after germination), and the others 7 and 14 days later ( $n=4$ per harvest and treatment). At each harvest, plant material was divided into leaf blades, culms (sheath and stem) and roots. Leaf blades were removed and their areas were measured using a leaf area meter (LI-3000, with conveyor belt assembly, LI-3050; Li-Cor, Inc., Lincoln, NE, USA). Roots were washed free of soil using a manually manipulated jet spray of water. Plant dry mass was obtained by drying the plant material at $65^{\circ} \mathrm{C}$ for 48 hours. At each harvest, leaf, culm and root mass ratios (respectively, leaf, culm and root dry mass per unit of dry mass of whole plant, LMR, CMR and RMR) were calculated according to Hunt (1990). Relative growth rate (change in total dry mass per total dry mass of plant per day, RGR) was also calculated for each harvest interval.

The length of a young expanding leaf blade (with the ligule not yet exposed) of a vegetative tiller of each plant was measured with a ruler at around the same time every day. Leaves being measured were marked with a plastic ring. Once the ligule was exposed, a new leaf, on the same plant, was marked and measured. Daily leaf elongation was calculated as the difference between leaf lengths of two consecutive days.

Net photosynthesis (A) and stomatal conductance were measured with an infrared gas analyzer (LI-6400, Li-Cor, Inc., Lincoln, NE, USA). Measurements were made nine days after flooding was imposed and also at the end of the experiment, on one young, fully expanded blade of a vegetative tiller on each plant. Gas exchange parameters were calculated on a leaf area basis. On both occasions, measurements were made in situ, between 9 am and 11 am local time, with a PPFD of $473 \pm 24$ (first evaluation) and $675 \pm 11$ (second evaluation) $\mu \mathrm{mol} \mathrm{m} \mathrm{m}^{-2} \mathrm{~s}^{-1}$ (mean \pm s.e.).

Pots were arranged in a completely randomized design with four replications. Differences in dry mass production 
and allocation, net photosynthesis, stomatal conductance and relative growth rate were assessed by two-way analyses of variance (ANOVA) with treatments (control and flooding) and accessions as main effects. Differences in leaf elongation rate throughout the experimental period were assessed by three-way ANOVA with treatments, accessions and evaluation dates as main effects. For adventitious root dry mass production, differences among accessions, in flooded plants, were tested by one-way ANOVA followed by Duncan test. Because no adventitious roots were found in accession BRA003441 (dry mass production $=0$ in all replications), it was omitted from the ANOVA (Finney, 1989). The assumption of homogeneity of variances and normality were tested for each ANOVA and, when necessary, data were $\log$ transformed. Transformed values were back transformed for presentation. Post hoc contrasts were calculated for assessing differences between treatments or within days and between treatments whenever appropriate.

Cluster analysis was used with the objective of grouping together those accessions having the greatest similarities in their relative tolerance to flooding, in the form of a hierarchical tree diagram. Data for cluster analysis were the mean difference between control and flooded plants in net photosynthesis, stomatal conductance, leaf elongation rate, leaf and root dry mass production, leaf area, number of tillers and plant height. The rationale being: the lower the difference between control and flooded plants, the higher the relative tolerance to flooding. Also, the relative increase in biomass allocated to culms under flooding (considered a negative characteristic) and an index indicating the ability of each accession to produce adventitious roots under flooding (considered a positive characteristic) were included in the cluster analysis. All data were standardized to a mean of 0 and a standard deviation of 1 before conducting the analysis. The clustering method was complete linkage. The number of clusters (i.e., accession discrimination by groups, according to their relative tolerance to flooding) was determined according to Dias-Filho et al. (1994).

The statistical package STATISTICA for Windows release 5.5 (StatSoft, Inc., Tulsa, USA) was used for all computations of the data.

\section{Results and Discussion}

The ANOVA for relative growth rate (RGR) showed a significant effect for treatment $\left(\mathrm{F}_{1,64}=15.8\right.$; $\mathrm{P}<0.001)$. Differences between treatments, within the same accession, assessed by post hoc contrasts indicated that only the accessions BRA000591 (cultivar Marandu) and BRA004308 had their RGR significantly reduced by flooding $\left(\mathrm{F}_{1,64} \geq 4.67 ; \mathrm{P} \leq 0.03\right)$ (Figure 1).

Flooding caused a significant reduction in leaf dry mass production in all accessions (post hoc contrasts, $F_{1,29} \geq 9.95 ; P \leq 0.004$ ) (Figure 2). For culm dry mass, only in BRA003441 it was not possible to detect statistical differences between treatments. In all other accessions, culm dry mass was significantly lower in flooded plants (Figure 2). A statistically significant decrease in root dry mass production in response to flooding could be detected in accessions BRA000591 (cultivar Marandu), BRA002844 and BRA004308 $\left(\mathrm{F}_{1,29} \geq 5.63 ; \mathrm{P} \leq 0.02\right)$. However, in accessions BRA003441 and BRA004391, root dry mass also showed a tendency to be relatively lower in flooded plants (Figure 2).

Biomass allocation showed a consistent response among accessions (Table 1). For all accessions,

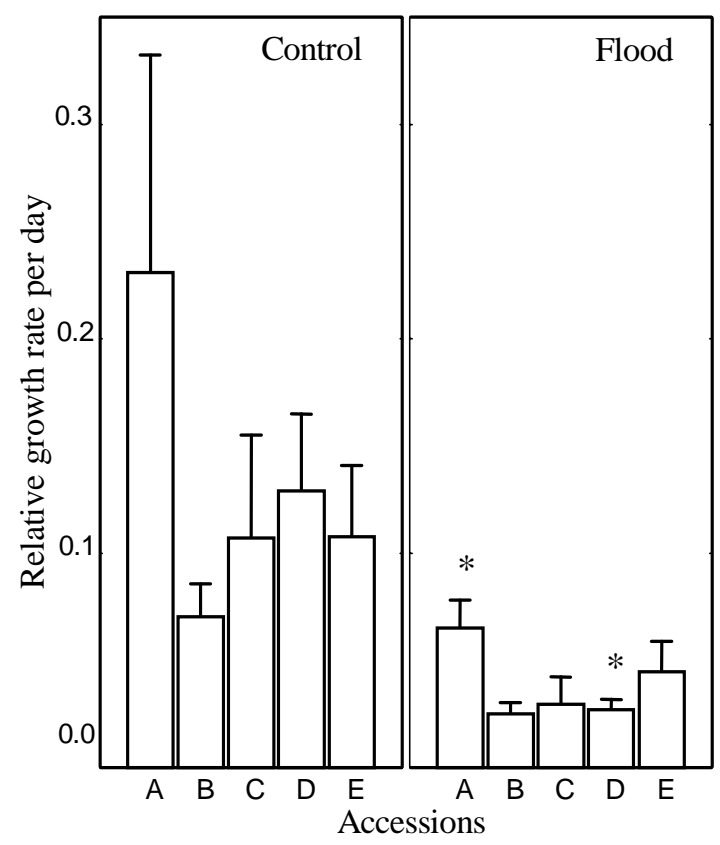

Figure 1. Relative growth rate of Brachiaria brizantha accessions BRA000591 cultivar Marandu (A), BRA003441 (B), BRA002844 (C), BRA004308 (D) and BRA004391 (E), under flooding and controlled conditions. Data are means \pm s.e. $(n=8)$. An asterisk indicates that the difference between treatments was statistically significant for that particular accession (post hoc contrasts; $\mathrm{P}<0.05$ ). 
proportion of biomass allocated to leaves (LMR) had a tendency to decrease under flooding. This effect, however, was not statistically significant in any accession. Biomass allocated to roots (RMR) was similar between treatments in BRA004391, but significantly lower in flooded plants of all other accessions. Flooding also promoted an increase in biomass allocation to culms (CMR) in BRA000591 (cultivar Marandu), BRA003441 and BRA004308.

The mean number of tillers per plant was significantly reduced by flooding in accessions BRA002844, BRA004308 and BRA004391.

Flooding often reduces total plant dry mass (Yamamoto et al., 1995; Lopez \& Kusar, 1999) and has a markedly detrimental effect on root dry mass, which is particularly sensitive to oxygen deficiency. Even grass species with a known tolerance to flooding show a shift in carbon allocation from below- to above-ground components under flooding (Naidoo

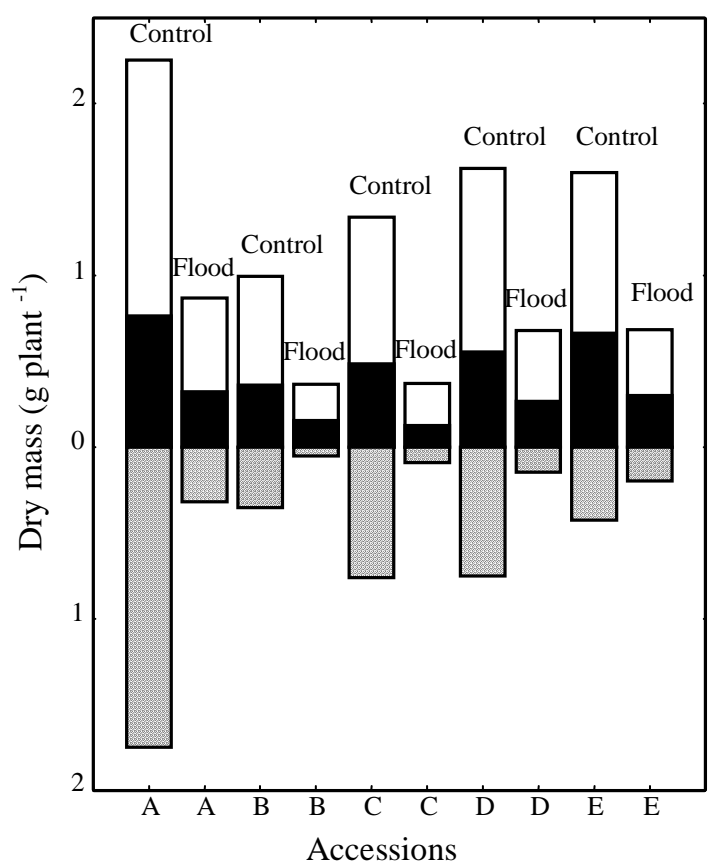

Figure 2. Mean values of dry mass at final harvest of Brachiaria brizantha accessions BRA000591 cultivar Marandu (A), BRA003441 (B), BRA002844 (C), BRA004308 (D) and BRA004391 (E), for each root (hatched area), culm (dark area) and leaf (blank area) component, under controlled and flooding conditions $(\mathrm{n}=4$ for each accession, component and treatment).
\& Naidoo, 1992; Naidoo \& Mundree, 1993; Baruch, 1994a; Loreti \& Oesterheld, 1996; Dias-Filho \& Carvalho, 2000). The reason for that is the deleterious effect flooding has on root formation and growth and the induction of root decay it causes (Kozlowski, 1997). Since flooding often occurs during the rainy season, plants that have suffered substantial reductions in root system size during flooding could be more sensitive to drought, during the subsequent dry season.

No adventitious roots were observed in BRA003441. In BRA004391, adventitious root production was statistically higher than in accessions BRA002844 and BRA004308, but similar to BRA000591 (cultivar Marandu) (Figure 3).

Flooding tolerance seems to be well related to adventitious root formation (Armstrong et al., 1994). In the flooding-tolerant tropical grass Hymenachne amplexicaulis, the capacity to form adventitious root is considered one of its major adaptation attributes to flooding (Kibbler \& Bahnisch, 1999). The same condition has also been proposed for the herbaceous flood-tolerant legume Lotus glaber (Vignolio et al., 1999) and for soybean (Bacanamwo \& Purcell, 1999).

In the present study, the patterns of adventitious root formation in the accessions studied were indeed highly correlated to their overall relative tolerance to flooding.

Table 1. Leaf mass ratio (LMR), culm mass ratio (CMR) and root mass ratio (RMR), at the last evaluation date, of Brachiaria brizantha accessions under flooding and control treatments $^{(1)}$.

\begin{tabular}{|c|c|c|c|}
\hline Treatment & LMR & CMR & RMR \\
\hline \multicolumn{4}{|c|}{ BRA000591 } \\
\hline Control & $0.41(0.05)^{\mathrm{ns}}$ & $0.20(0.02)^{*}$ & $0.38(0.05)^{*}$ \\
\hline Flooding & $0.48(0.04)$ & $0.27(0.01)$ & $0.24(0.05)$ \\
\hline \multicolumn{4}{|c|}{ BRA003441 } \\
\hline Control & $0.48(0.04)^{\mathrm{ns}}$ & $0.26(0.01)^{*}$ & $0.25(0.03) *$ \\
\hline Flooding & $0.49(0.06)$ & $0.36(0.04)$ & $0.12(0.01)$ \\
\hline \multicolumn{4}{|c|}{ BRA002844 } \\
\hline Control & $0.44(0.04)^{\mathrm{ns}}$ & $0.24(0.01)^{\mathrm{ns}}$ & $0.30(0.06)^{*}$ \\
\hline Flooding & $0.55(0.04)$ & $0.27(0.04)$ & $0.16(0.03)$ \\
\hline \multicolumn{4}{|c|}{ BRA004308 } \\
\hline Control & $0.46(0.04)^{\mathrm{ns}}$ & $0.24(0.01)^{*}$ & $0.29(0.04) *$ \\
\hline Flooding & $0.50(0.03)$ & $0.32(0.03)$ & $0.17(0.02)$ \\
\hline \multicolumn{4}{|c|}{ BRA004391 } \\
\hline Control & $0.46(0.02)^{\mathrm{ns}}$ & $0.33(0.01)^{\mathrm{ns}}$ & $0.21(0.02)^{\mathrm{ns}}$ \\
\hline Flooding & $0.44(0.03)$ & $0.33(0.01)$ & $0.22(0.03)$ \\
\hline
\end{tabular}

Pesq. agropec. bras., Brasília, v. 37, n. 4, p.439-447, abr. 2002 
A significant accession $\mathrm{x}$ treatment interaction was detected for leaf elongation rate $\left(\mathrm{F}_{4,338}=8.39\right.$; $\mathrm{P}<0.0001$ ) (Figure 4). Post hoc contrasts of differences between treatments, within the same accession, showed that all accessions had their mean leaf elongation rate, for the entire evaluation period, significantly reduced by flooding $\left(\mathrm{F}_{1,338} \geq 81.4\right.$; $\mathrm{P}<0.0001$ ).

Leaf elongation rate has been proposed as an early detection mechanism for determining flood tolerance in Brachiaria spp. (Dias-Filho \& Carvalho, 2000). In other grass species and accessions, leaf elongation rate is usually also associated to relative tolerance to flooding (Lizaso \& Ritchie, 1997; Yamauchi \& Biswas, 1997).

In the present study, although, as expected, flooding significantly reduced leaf elongation rate

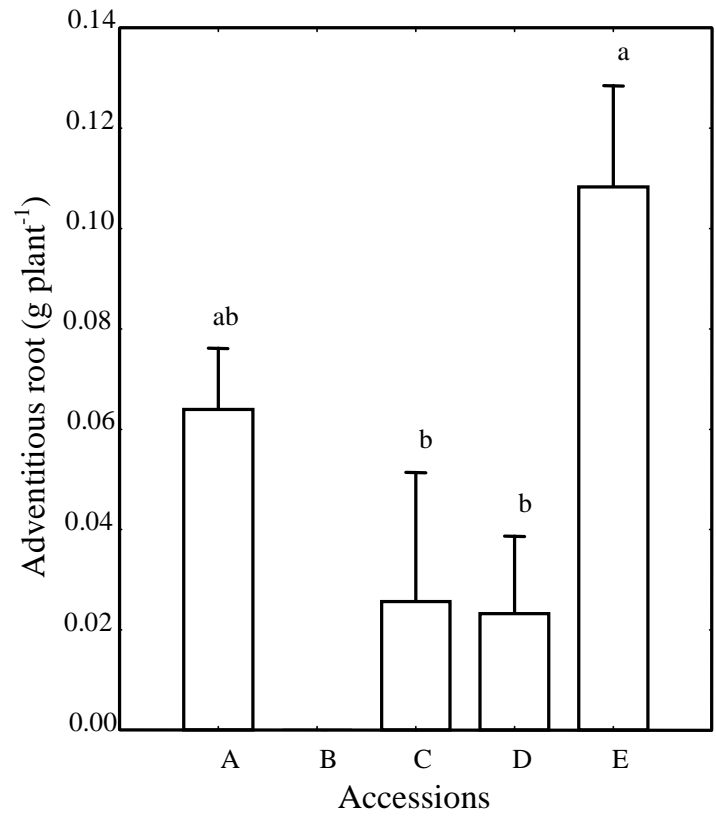

Figure 3. Adventitious root dry mass at final harvest of Brachiaria brizantha accessions BRA000591 cultivar Marandu (A), BRA003441 (B), BRA002844 (C), BRA004308 (D) and BRA004391 (E), subjected to flooding. Data are means \pm s.e. $(n=4)$. Columns with different letters are significantly different $(\mathrm{P}<0.05$, Duncan test $)$.

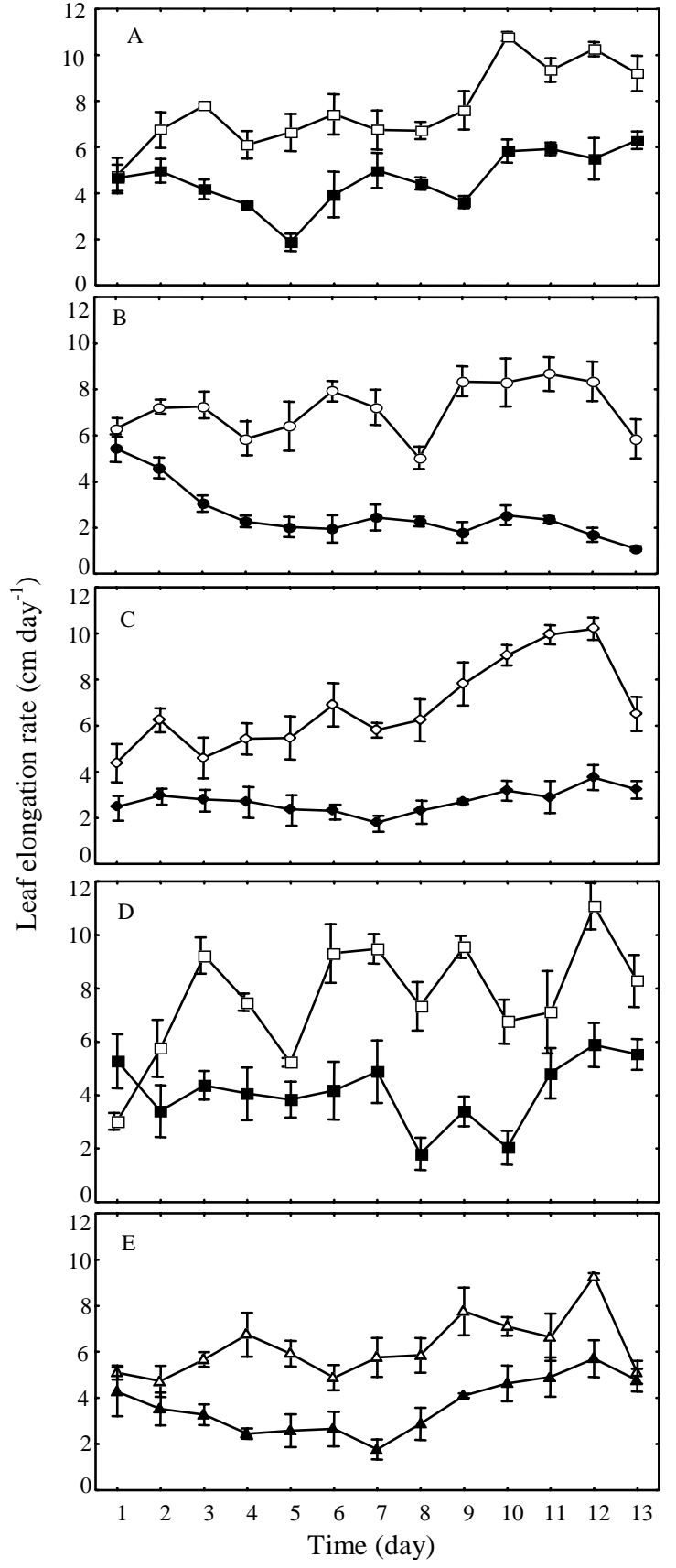

Figure 4. Leaf elongation rate of Brachiaria brizantha accessions BRA000591 cultivar Marandu (A), BRA003441 (B), BRA002844 (C), BRA004308 (D) and BRA004391 (E), under flooding (closed symbols) and controlled (open symbols) conditions. Each point represents the mean \pm s.e. $(n=4)$.

Pesq. agropec. bras., Brasília, v. 37, n. 4, p. 439-447, abr. 2002 
of all accessions, the intensity of this response contrasted among accessions, being highest in BRA003441 and lowest in BRA004391.

Net photosynthesis was significantly reduced by flooding in all accessions at both evaluation dates (Figure 5). This reduction in photosynthetic capacity was higher for BRA000591 (42.4\%), at the first evaluation, and for BRA003441 (63\%), at the last evaluation date. On both occasions, flooded BRA004391 had the lowest mean reduction in net photosynthesis ( $29.8 \%$ and $13.8 \%$, respectively).

The photosynthetic response of cultivar Marandu (BRA000591) to flooding followed a similar pattern of that observed by Dias-Filho \& Carvalho (2000). However, net photosynthesis of flooded plants was substantially higher than in that study, probably reflecting the periodical fertilization of these plants in the present study.

Comparing the photosynthetic response at the two evaluation dates, it can be seen that, for all accessions, there was a steady decline in net photosynthesis of control plants between the first and the last evaluation dates. This decline was probably a consequence of some degree of transient water deficit caused by the higher transpirational demand (higher leaf mass) of these plants. For flooded plants, only BRA003441 and, to some extent, BRA002844 showed a substantial decline in photosynthetic response through time. All other accessions maintained photosynthetic capacity (Figure 5).

Photosynthetic response is very sensitive to flooding (Pezeshki, 1994), and even in the flood-tolerant grasses Echinochloa polystachya (Baruch, 1994b; Piedade et al., 1994) and Brachiaria mutica (Baruch, 1994b), net photosynthesis was significantly decreased in flooded plants. However, for the flooded-tolerant grass Brachiaria humidicola, Dias-Filho \& Carvalho (2000) could not find significant differences in net photosynthesis between control and flooded plants, after 14 days of continuous flooding (water level $3 \mathrm{~cm}$ above soil surface).

For stomatal conductance, a similar response was observed, however, differences between treatments could not be detected in BRA004391 (Figure 6). In all

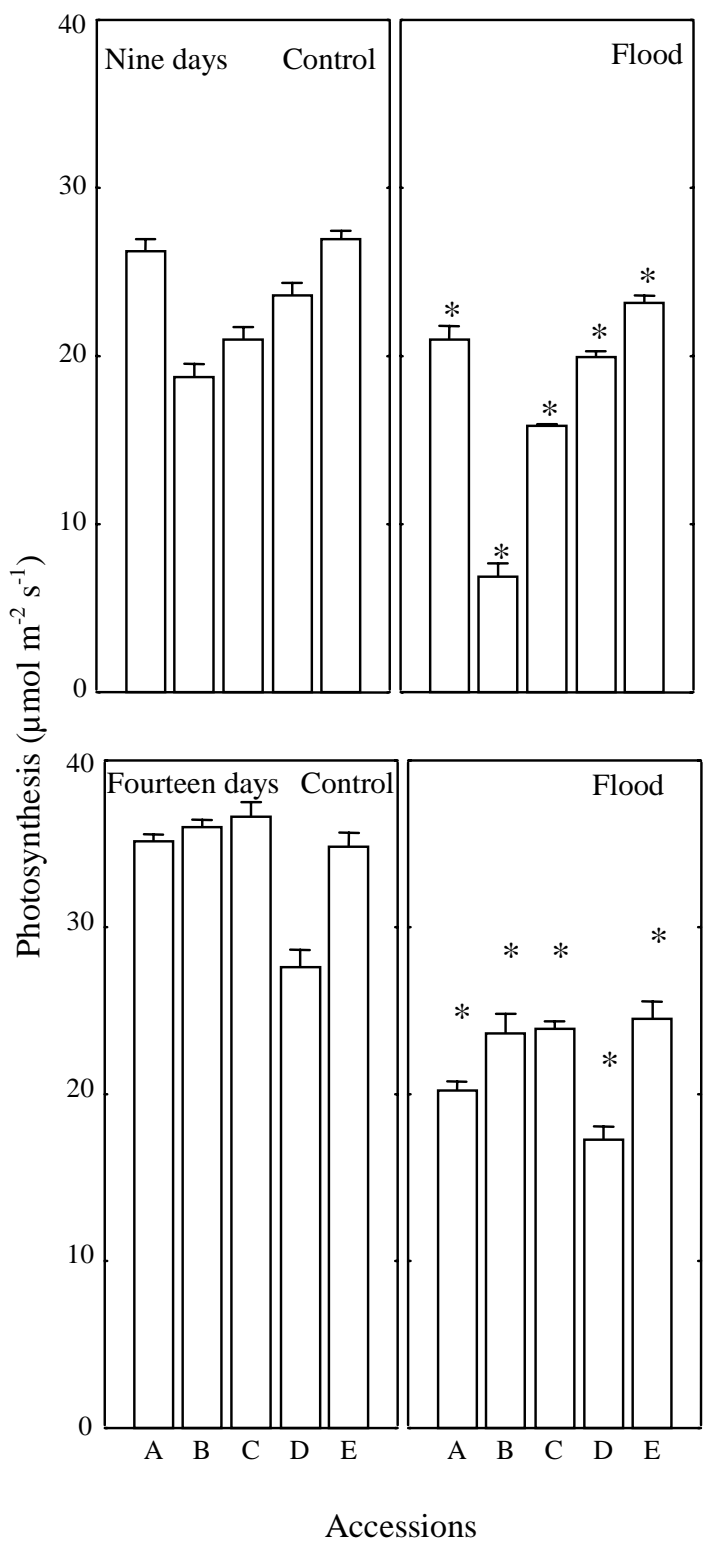

Figure 5. Net photosynthesis of Brachiaria brizantha accessions BRA000591 cultivar Marandu (A), BRA003441 (B), BRA002844 (C), BRA004308 (D) and BRA004391 (E), under flooding and controlled conditions, nine and fourteen days after the beginning of the experiment. Data are means \pm s.e. $(n=4)$. An asterisk indicates that the difference between treatments within the same date was statistically significant for that particular accession (post hoc contrasts; $\mathrm{P}<0.05$ ). 
other accessions, stomatal conductance was always higher in control plants.

Stomatal conductance in flooded plants usually follows the same pattern of photosynthetic response (Lopez \& Kusar, 1999; Olivella et al., 2000). In a study of physiological responses to flooding in three species of Brachiaria (Dias-Filho \& Carvalho, 2000), stomatal response was also found to be closely correlated to photosynthetic rate and flooding tolerance.

Based on the dendrogram from the hierarchical cluster analysis (Figure 7), it can be seen that the five accessions tested clearly differed in their relative tolerance to flooding. Four distinct clusters (groups) of $B$. brizantha accessions were identified. These

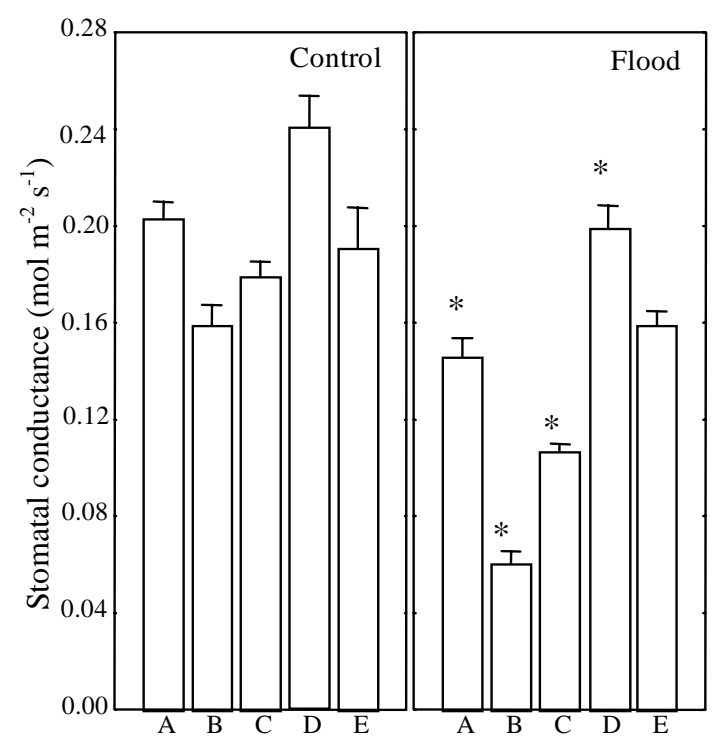

Accessions

Figure 6. Stomatal conductance of Brachiaria brizantha accessions BRA000591 cultivar Marandu (A), BRA003441 (B), BRA002844 (C), BRA004308 (D) and BRA004391 (E), under flooding and controlled conditions. Data are means \pm s.e. $(n=4)$. An asterisk indicates that the difference between treatments was statistically significant for that particular accession (post hoc contrasts; $\mathrm{P}<0.05$ ). clusters are labeled in Figure 7 according to their relative tolerance to flooding. Accessions BRA004391, BRA000591 (cultivar Marandu) and BRA003441 were grouped, individually, in three clusters of, respectively, high, low and very low relative tolerance to flooding. Accessions BRA002844 and BRA004308 were grouped together in a cluster of intermediate flood tolerance.

It is important to emphasize, however, that the above classification was based on relative responses to flooding of the five accessions, and, even accession BRA004391, classified as highly tolerant to flooding, had many aspects of its performance negatively affected by this stress.

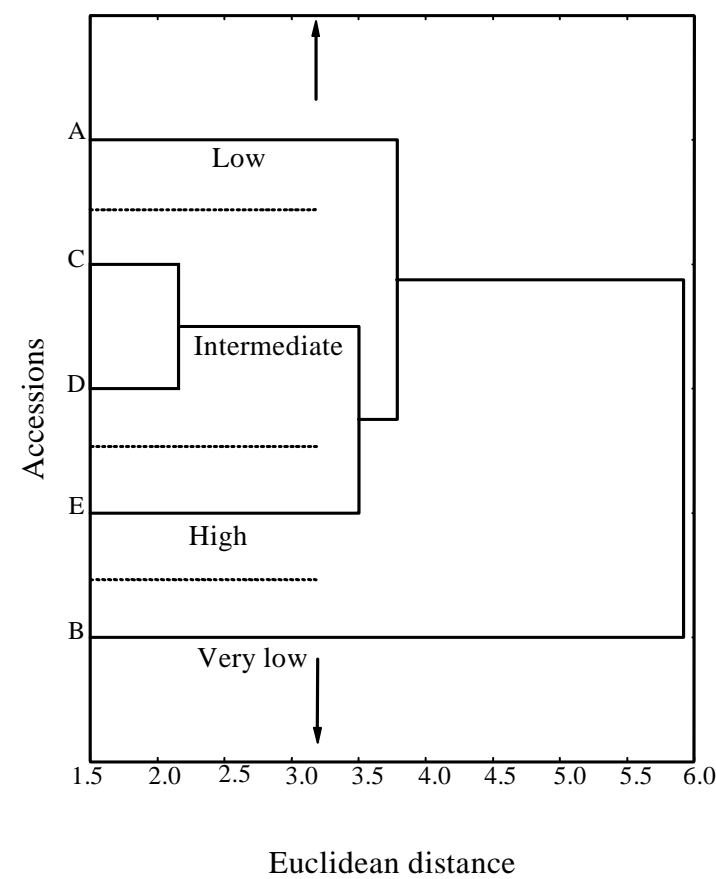

Figure 7. Dendrogram of the relative tolerance to flooding of Brachiaria brizantha accessions BRA000591 cultivar Marandu (A), BRA003441 (B), BRA002844 (C), BRA004308 (D) and BRA004391 (E). The clustering method was complete linkage and the distance was Euclidean. Clusters are limited by dotted lines and identified by names. Arrows indicate the selected cutoff distance to retain clusters. 


\section{Conclusions}

1. The five accessions tested differ in relative tolerance to flooding.

2. Brachiaria brizantha BRA004391 is the accession most tolerant to flooding.

3. Accession BRA003441 is the most sensitive, followed by BRA000591 (cultivar Marandu).

4. Accessions BRA002844 and BRA004308 are ranked as intermediate in flooding tolerance.

\section{Acknowledgments}

To Cacilda B. do Valle and Francisco H. Dübbern de Souza (Embrapa-Centro Nacional de Pesquisa de Gado de Corte) for supplying the seeds used in this trial; to the former undergraduate PIBIC/CNPq fellow Letitia Brasil Claudino Cruz for her skilful technical assistance during the experiment evaluation; to two anonymous reviewers for the valuable suggestions to improve this manuscript.

\section{References}

ARGEL, P. J.; KELLER-GREIN, G. Regional experience with Brachiaria: Tropical America-humid lowlands. In: MILES, J. W.; MAASS, B. L.; VALLE, C. B. do (Ed.). Brachiaria: biology, agronomy, and improvement. Cali: Centro Internacional de Agricultura Tropical, 1996. p. 205221.

ARMSTRONG, W.; BRÄNDLE, R.; JACKSON, M. B. Mechanisms of flood tolerance in plants. Acta Botanica Neerlandica, Oxford, v. 43, p. 307-358, 1994.

BACANAMWO, M.; PURCELL, L. C. Soybean root morphological and anatomical traits associated with acclimation to flooding. Crop Science, Madison, v. 39, p. 143-149, 1999.

BARUCH, Z. Responses to drought and flooding in tropical forage grasses. I: biomass allocation, leaf growth and mineral nutrients. Plant and Soil, Dordrecht, v. 164, p. 87 $96,1994 \mathrm{a}$.

BARUCH, Z. Responses to drought and flooding in tropical forage grasses. II: leaf water potential, photosynthesis rate and alcohol dehydrogenase activity. Plant and Soil, Dordrecht, v. 164, p. 97-105, 1994b.

DIAS-FILHO, M. B. Pastagens cultivadas na Amazônia oriental brasileira: processos e causas de degradação e es- tratégias de recuperação. In: DIAS, L. E.; MELLO, J. W. V. (Ed.). Recuperação de áreas degradadas. Viçosa: UFV/ Sociedade Brasileira de Recuperação de Áreas Degradadas, 1998. p. 135-147.

DIAS-FILho, M. B.; CARVALhO, C. J. R. de. Physiological and morphological responses of Brachiaria spp. to flooding. Pesquisa Agropecuária Brasileira, Brasília, v. 35, n. 10, p. 1959-1966, out. 2000.

DIAS-FILHO, M. B.; SIMÃO NETO, M.; SERRÃO, E. A. S. Cluster analysis for assessing the agronomic adaptation of Panicum maximum Jacq. accessions. Pesquisa Agropecuária Brasileira, v. 29, n. 10, p. 15091516, out. 1994.

FINNEY, D. J. Was this in your statistics textbook? V: transformation of data. Experimental Agriculture, Cambridge, England, v. 25, p. 165-175, 1989.

HUNT, R. Basic growth analysis for beginners. London: U. Hyman, 1990. 112 p.

KIBBLER, H.; BAHNISCH, L. M. Physiological adaptations of Hymenachne amplexicaulis to flooding. Australian Journal of Agricultural Research, Collingwood, v. 39, p. 429-435, 1999.

KOZLOWSKI, T. T. Responses of woody plants to flooding and salinity. Tree Physiology, Victoria, v. 1, 1997. Disponível em: http://www.heronpublishing.com/tp/ monograph/kozlowski.pdf. Acesso em: 13 jan. 2001.

LIZASO, J. I.; RITCHIE, J. T. Maize shoot and root response to root zone saturation during vegetative growth. Agronomy Journal, Madison, v. 89, p. 125-134, 1997.

LOPEZ, O. R.; KUSAR, T. A. Flood tolerance of four tropical tree species. Tree Physiology, Victoria, v. 19, p. $925-932,1999$.

LORETI, J.; OESTERHELD, M. Intraspecific variation in the resistance to flooding and drought in populations of Paspalum dilatatum from different topographic positions. Oecologia, Berlin, v. 108, p. 279-284, 1996.

MEDINA, E.; MOTTA, N. Metabolism and distribution of grasses in tropical flooded savannas in Venezuela. Journal of Tropical Ecology, Cambridge, England, v. 6, p. 77-89, 1990.

NAIDOO, G.; MUNDREE, S. G. Relationship between morphological and physiological responses to waterlogging and salinity in Sporobolus virginicus (L.) Kunth. Oecologia, Berlin, v. 93, p. 360-366, 1993. 
NAIDOO, G.; NAIDOO, S. Waterlogging responses of Sporobolus virginicus (L.) Kunth. Oecologia, Berlin, v. 90, p. 445-450, 1992.

OLIVELLA, C.; BIEL, C.; VENDRELL, M.; SAVE, R. Hormonal and physiological responses of Gerbera jamesonii to flooding stress. HortScience, Alexandria, v. 35, p. 222-225, 2000.

PEZESHKI, S. R. Plant response to flooding. In: WILKINSON, R. E. (Ed.). Plant-environment interactions. New York: M. Dekker, 1994. 616 p.

PIEDADE, M. T. F.; LONG, S. P.; JUNK, W. J. Leaf and canopy photosynthetic $\mathrm{CO}_{2}$ uptake of a stand of Echinochloa polystachya on the Central Amazon flood plain are the high potential rates associated with the $\mathrm{C}_{4}$ syndrome realized under the near-optimal conditions provided by this exceptional natural habitat? Oecologia, Berlin, v. 97, p. 193-201, 1994.

RAM, S. Role of alcohol dehydrogenase, malate dehydrogenase and malic enzyme in flooding tolerance in
Brachiaria species. Journal of Plant Biochemistry and Biotechnology, New Delhi, v. 9, p. 45-47, 2000.

SIMÃO NETO, M.; DIAS-FILHO, M. B.; SERRÃO, E. A. S. Avaliação da adaptação de acessos de Brachiaria spp. para a Amazônia Oriental do Brasil. Pasturas Tropicales, Cali, v. 17, p. 9-13, 1995.

VIGNOLIO, O. R.; FERNANDEZ, O. N.; MACEIRA, N. O. Flooding tolerance in five populations of Lotus glaber Mill. (Syn. Lotus tenuis Waldst. et Kit.). Australian Journal of Agricultural Research, Collingwood, v. 50, p. 555-559, 1999.

YAMAMOTO, F.; SAKATA, T.; TERAZAWA, K. Physiological, morphological and anatomical responses of Fraxinus mandshurica seedlings to flooding. Tree Physiology, Victoria, v. 15, p. 713-719, 1995.

YAMAUCHI, M.; BISWAS, J. K. Rice accession difference in seedling establishment in flooded soil. Plant and Soil, Dordrecht, v. 189, p. 145-153, 1997. 